\title{
IMPACT OF EURO-MARKETS ON THE UNITED STATES BALANCE OF PAYMENTS*
}

\author{
Fred H. KLorstock $f$
}

The decade beginning in rg60 has witnessed the emergence of broad and active international financial markets-the so-called Euro-money and Euro-capital marketswhich have by now become the main conduits for the transmission of short- and long-term capital across national borders. The beginnings of the Euro-money market -also referred to as the Euro-currency deposit market-actually date back to the mid-r950s, when several major European banks began to bid for time deposits denominated in currencies other than their own and to employ these funds in foreign loan markets. The introduction of nonresident convertibility throughout Western Europe at the end of $195^{8}$ and the concurrent relaxation of exchange controls in many European countries broadened these markets. But not until the early I96os did they achieve really impressive proportions. By now, the Euro-dollar market, ${ }^{1}$ the most important sector of the Euro-currency deposit market, has far outpaced the New York and London money markets in the employment of privately-held nonresident dollar balances. And while these two national money markets are still the major receptacles for central banks' international reserves, the Euro-dollar market has increasingly become an important outlet, directly and indirectly, for dollar balances held by central banks. Presently, the market's net size exceeds $\$ 25$ billion.

The distinctive characteristic of the Euro-bond market is the simultaneous flotation of interest-bearing securities in a large number of countries by multinational underwriting syndicates for sale to an investment clientele which resides in many parts of the world. These securities are usually denominated in dollars, or at any rate in a currency other than those of the countries in which most of the bonds are sold. In these respects, the Euro-bond market differs from the traditional foreign bond markets, in which securities issues of foreign borrowers are underwritten by national syndicates. In the traditional market, securities are sold principally in the country of the syndicate, and denominated in the currency and offered under the laws and regulations of that country. Internationally syndicated issues are not subject to such

- This paper is adapted from an address to the Washington Conference on Transatlantic Direct Investment and the Balance of Payments, Institute for International and Foreign Trade Law, Georgetown University, Washington, D.C., Sept. 26, 1968.

† Manager, Internatonal Research Department, Federal Reserve Bank of New York.

This article expresses the personal views of the author and carries no implications as to the views of the Federal Reserve Bank of New York.

${ }^{2}$ By a generally accepted definition, Euro-dollars come into existence when a domestic or foreign holder of dollar demand deposits in the United States places them on deposit in a bank outside the United States, but the term also applies to the dollars that banks abroad acquire with their own or foreign currencies and then employ for placement in the market or for loans to customers. The Euro-dollar market is essentially a market for dollar call and time deposits in banks outside the United States. 
regulation since they are offered in a supranational market that is foreign to both borrower and lender.

The Euro-bond market began to emerge in the early ig6os in response to growing investor interest in foreign currency issues. It broadened considerably in 1963 and r964 after the U.S. Government announced (and subsequently imposed retroactively) an equalization tax on interest received by U.S. residents from long-term securities issued by borrowers in developed countries. ${ }^{2}$ This tax made long-term borrowing in the United States prohibitively costly for such users of credit and led to the virtual closure of the New York capital market for foreign bond issues of almost all industrial countries. An even greater impetus to the growth of the Euro-bond market came from the voluntary guidelines on foreign direct investment issued under the U.S. balance of payments program of $196_{5}$, as these caused American companies to turn to foreign capital markets for the financing of their direct investments abroad. Beginning in that year, many leading American corporations made their appearance in the Euro-bond market through special international finance subsidiaries incorporated in the United States or organized under the laws of foreign countries. These affiliates soon became the most important single group of borrowers. At the end of rg68, total Euro-bonds outstanding amounted to almost \$9 billion, of which more than three quarters had been placed between I966 and I968 and about $\$ 3.5$ billion were securities of U.S. companies.

\section{Capital Movements Through the Euro-Dollar Market}

Capital movements through the Euro-dollar market affect the U.S. balance of payments in a variety of ways. Outflows of U.S. funds into the market add to aggregate foreign dollar balances and thus worsen our payments position as measured by the liquidity balance. They also affect the official reserve transactions balance unless the entire outflow is retained by private foreigners. ${ }^{3}$ Flows from the market into the United States do not affect aggregate foreign holdings of dollars, but they may lead to shifts of dollar balances between official and private holders. In addition, the very existence of the market affects the U.S. balance of payments by providing foreign borrowers a viable alternative to loans from American banks. It also provides foreign investors of short-term funds an opportunity to substitute dollar deposits in foreign banks for investments in U.S. money market assets.

\footnotetext{
${ }^{2}$ INT. REv. CoDe of I954, $\$ 4911$.

${ }^{3}$ The liquidity balance is drawn by netting the change in our gold and official convertible exchange reserves against the change in those liabilities to foreigners defined as liquid. Under the liquidity balance concept, such changes are considered as financing or settling the over-all balance. The official reserve transactions concept differs from that of the liquidity balance in that it is based on the change in official reserve assets (defined in the same manner as for the liquidity balance) less the change in both liquid and certain nonliquid liabilities to "official" foreigners.
} 
A. Flows From the United States to the Euro-Dollar Market

In the early Ig6os, the Euro-dollar market attracted relatively sizable amounts of domestic cash reserves of major American corporations. They were drawn to the market by high yields on Euro-dollar deposits, which have almost consistently been above those available in the United States for negotiable time certificates of deposit. Foreign banks have been able to offer better rates for corporate dollar deposits than American banks because of their willingness to operate in their borrowing and lending transactions within very narrow profit margins. They are not subject to interest rate ceilings on dollar deposits and can pay interest on very short-dated, even on overnight, deposits. American banks, on the other hand, must comply with the Federal Reserve Board's regulation $\mathrm{Q}^{4}$ issued under the authority of section rg of the Federal Reserve Act. ${ }^{5}$ This regulation imposes ceilings on rates payable on time deposits by U.S. banks and prevents the banks from paying interest on deposits with maturities of less than thirty days. ${ }^{\circ}$

Dollar time deposits in foreign banks have, moreover, certain characteristics that make them look more attractive to U.S. investors than other investment media available in foreign money markets. Except for Canadian finance paper denominated in U.S. dollars, short-term investments abroad by U.S. corporations require the purchase of foreign currencies, which in turn makes it desirable for the buyer to cover the exchange risk. When investing in dollar time deposits in foreign banks, there is no need for hedging against currency risks. It is probably safe to say that in the absence of foreign dollar time deposit facilities available in the Euro-dollar market many U.S. corporations that have used the market would not have placed funds abroad. Thus the market has, at times, given rise to outflows of short-term capital from the United States that would not have occurred otherwise.

Since I965, however, U.S. capital outflows into the Euro-dollar market have been effectively curbed by the voluntary and mandatory restraints adopted in response to the President's program to improve the nation's balance of payments. In April rg65 the Commerce Department, under authority assigned by the President, issued guidelines regarding nonfinancial corporations' short-term financial assets held abroad. These guidelines called for the gradual repatriation during ig65 of both deposits in foreign banks and other foreign short-term investments until such holdings were at the level outstanding on December $3 \mathrm{r}$, rg63. In subsequent years these guidelines were reiterated and strengthened. For example, in connection with the I968 program of the Commerce Department, the Secretary of Commerce asked firms with short-term assets abroad to limit their holdings to a minimum level, retaining only what was necessary to cover working requirements. The mandatory

\footnotetext{
412 C.F.R. $\$ 217$ (1969).

${ }^{5}$ Federal Reserve Act, 12 U.S.C. $\$ \S 37$ I (a),(b) (Ig64).

${ }^{a}{ }_{2}$ C.F.R. $\$ \$ 217.2-.3$ (I969).

'U.S. Dep't of Commerce, Voluntary Program to Improve the Balance of Payments, Guidelines on Short Trem Financiat Assets (x965).
} 
program initiated in I 968 stipulated further measures for the withdrawal of corporate funds from the Euro-dollar market. ${ }^{8}$ Any "direct investor"--that is, individual or corporation owning or acquiring more than ten per cent of the voting power of a foreign company-was required, prior to June 30, rg68, to reduce his bank deposits and other short-term financial assets held abroad to an amount not exceeding average end-of-month balances during 1965 and 1966 . However, beginning in March 1968 , under an agreement reached between the United States and Canada, deposits of U.S. residents in Canadian banks were exempted from this provision."

Another exemption applied to foreign bank deposits of one particular group of corporations in the United States that in recent years has maintained large and at times rapidly expanding holdings of foreign-source funds (as distinct from U.S.source) in the Euro-dollar market. These are the so-called "Delaware" corporations, i.e., international finance subsidiaries of U.S. corporations, usually incorporated in Delaware for the purpose of floating Euro-bonds abroad. Such bonds, to be salable overseas, must be free of the U.S. withholding tax with respect to interest paid to the bondholders. The Internal Revenue Code requires American corporations paying interest to nonresident aliens to withhold tax at the rate of thirty per cent if such interest is paid from gross income generated within the United States. ${ }^{10}$ But corporations can obtain exemption from this requirement if they can show, to the satisfaction of the Secretary of the Treasury, that less than twenty per cent of their gross income during the three-year period ending with the current tax year has been derived from sources within the United States. ${ }^{11}$ In order to obtain exempt status, Delaware corporations tend to place Euro-bond proceeds in the Euro-dollar market pending use of the funds for investments in debt and equity securities of their parent companies' foreign affiliates.

The Commerce Department's Office of Foreign Direct Investments (OFDI) ruled in its investment regulations that direct investors such as Delaware corporations may not make any net transfers of their own funds to foreign operating subsidiaries during any year if at the end of such year they hold liquid balances abroad which represent the proceeds of foreign long-term borrowings. ${ }^{12}$ In its explanation of this regulation, the OFDI states that "direct investment with the proceeds of long-term foreign borrowing does not have an immediate adverse effect on the U.S. balance of payments." ${ }^{13}$ In response and in an attempt to comply with the quota provisions of the investment program, U.S. direct investors toward the end of 1968 arranged for

\footnotetext{
${ }^{8}$ I5 C.F.R. $\$ 1000.203$ (e) (I969). These regulations are cited hereinafter as OFDI Reg. $\$$, omitting from each section reference to the prefix "rooo" which it bears in the Code of Federal Regulations.

- OFDI Reg. $\$ x 105$ ( $x 969$ ).

${ }^{10}$ INT. REv, CODE of I954, \$ I44T.

I1 Id. $\$ 86 \mathrm{r}$.

13 OFDI Reg. \$203 (1969).

${ }^{13}$ OFDI General Bulletin No. I, Interpretative Analyses and Statements, $\$$ B203, 33 Fed. Reg. $15 \times 65$ (I968).
} 
large borrowings in the Euro-dollar market by their foreign operating affiliates, which in turn employed the balances to pay off their parent companies' claims against them. This use of funds served to reduce net investment outflows from the United States by very substantial amounts and was a major factor contributing to the I 968 surplus in our liquidity balance. ${ }^{14}$

In addition to nonfinancial corporations, a variety of American financial institutions-commercial banks, insurance companies, pension funds, and investment companies-have been suppliers to the Euro-dollar market. Under the President's Balance of Payments Program of February 1965, the responsibility for curbing financial institutions' investments in short-term assets abroad was assigned to the Board of Governors of the Federal Reserve System. With regard to banks, the Board, issued guidelines in March 1965 , requesting them to refrain from increasing their deposits abroad and to reduce them in a reasonable and orderly manner. ${ }^{15}$ In $\mathrm{I} 966$ the guidelines were tightened by asking the banks not to place their own funds abroad for short-term investment purposes, and this request was repeated in the guidelines in subsequent years. ${ }^{13}$ In 1968 , in response to the agreement reached between the United States and Canada, the Federal Reserve Board, like the Commerce Department, exempted deposits in Canadian banks. ${ }^{17}$

For nonbank financial institutions the Board issued guidelines in June 1965 , requesting such institutions not to increase investments of liquid funds abroad and adding that if current holdings exceeded those at the end of $x 963$ or 1964 , they should be reduced in a gradual and orderly manner to the lesser of these year-end totals. ${ }^{18}$ The 1966 guidelines requested that these investments be held to minimum practicable levels, ordinarily not to exceed the September 30 , rg65, total. ${ }^{10}$ In I968, however, the Board requested nonbank financial institutions to repatriate all their holdings of foreign liquid funds, except for those held in Canada. ${ }^{20}$

There is no doubt that the U.S. balance of payments program has set up effective barriers to the flow of U.S. capital to the Euro-dollar market and other international and foreign money markets. Consequently, the movement of domestic funds to foreign destinations has become much less responsive to interest rate changes in major foreign financial centers, and the monetary policy job of preventing large amounts of such funds from being transferred to foreign holders has become correspondingly easier. However, it should be noted that the relatively high interest yields available in the U.S. money market since 1966 would have limited placements of

\footnotetext{
${ }^{14}$ It should be noted, however, that another reason for the large repatriation of balances obtained by affiliates in the Euro-dollar market was the parent companies' desire to improve their domestic cash positions and to avoid borrowings from domestic banks at the prevailing high interest rates.

${ }^{15}$ 5I Fed. Reserve Bull. 371 (I965).

${ }^{10} 52$ Fed. Reserve Bull. I753 (1966).

${ }^{17} 54$ Fed. Reserve Bull. 262 (I968).

${ }^{18} 5$ I Fed. Reserve BuLl. 994 (I965).

${ }^{10} \mathrm{Id}$. at I693 (1965).

${ }^{20} 54$ Fed. Reserve Buli. II (Ig68).
} 
American funds in the Euro-dollar market in any event. In other words, monetary policy in the United States has also been an important factor during recent years in discouraging U.S. financial and nonfinancial corporations from placing their liquid funds abroad. This is evidenced by the fact that U.S. deposits in Canadian banks did not increase after the exemption of Canada from the balance of payments program.

\section{B. Flows From the Euro-Dollar Market to the United States}

When foreign banks draw on the Euro-dollar market for the purpose of placing funds with banks in the United States or making investments in the New York money market, aggregate liabilities of U.S. banks to foreigners do not change, and our liquidity balance is not affected. However, such operations may affect our balance as defined on the official reserve transactions basis. If, for example, an Italian bank purchases a dollar balance from its monetary authority and places this balance with, say, an overseas branch of a U.S. bank which retains these funds in its head office, foreign private deposits in the United States are increased at the expense of foreign official holdings, and our official reserve transactions balance consequently improves. The same is true if the Italian bank places these funds with a Canadian bank which transfers them to the account of its agency in the United States to enable the agency to make a loan to a New York securities dealer.

During recent years flows of funds from the Euro-dollar market to U.S. banks have been very substantial and have been of great benefit to our official reserve transactions balance. A major factor in these flows is that the market has offered U.S. banks opportunities to overcome a number of regulatory obstacles to their acquisition of foreign deposits. In their quest for foreign balances, U.S. banks are handicapped by the interest rate ceilings and interest rate payment prohibition of the Federal Reserve Board's Regulation Q. This regulation does not apply to deposits in the overseas branches of American banks or to the compensation paid by these banks to their branches for funds obtained abroad on their behalf. Equally important, balances held by overseas branches in their head offices, unlike foreign deposits in United States banks, are not subject to the legal reserve requirements provided by the Federal Reserve Board's Regulation D, 21 nor are they subject to the fees charged by the Federal Deposit Insurance Corporation. Finally, banks with overseas branches

\footnotetext{
${ }^{21}$ Under the Federal Reserve Board's Regulation D, I2 C.F.R. $\$$ 204.x (1969), borrowings by American banks from their foreign branches are currently exempt from reserve requirements. They are also exempt from Regulation Q rate ceilings. I2 C.F.R. $\$ 217.2$ (1969). However, in late June I969, the Federal Reserve Board proposed restrictions on the flow of Euro-dollars to U.S. banks. 34 Fed. Reg. 11214 (1969). Under the proposal, a 10\% reserve requirement on member bank borrowings from forcign branches over and above borrowings during a base period was to be added to Regulation M. With the tight credit restraint in the United States, domestic banks have been borrowing large amounts of dollars from the Euro-dollar market to meet the heavy loan demand from their customers. This incrcased demand in the Euro-dollar market raised interest rates in Europe, causing concern among forcign central bankers. See Wall Street Journal, June 26, 1969, at 3, col. I.
} 
can achieve substantial savings in reserve requirements by taking advantage of certain technical regulations of the Federal Reserve Board pertaining to the computations of deposits subject to reserve requirements. ${ }^{22}$

In 1968, balances held in American banks by their overseas branches increased by more than $\$ 2$ billion, and by June 1969 they amounted to more than $\$ 12$ billion, with almost all of these funds originating in the Euro-dollar market. Additional Eurodollar balances have been supplied directly to U.S. banks that do not have overseas branches. Euro-dollars have also been used for the purchase of loans in American bank portfolios, both by overseas branches and by foreign banks. In 1966 and 1968 these various capital inflows contributed importantly to the emergence of surpluses in the U.S. balance of payments as defined on the official reserve transactions basis.

There have been a great variety of other flows from the market to U.S. banks and to the New York money market. For instance, foreign banks have made use of the market to obtain dollar balances that they wanted for operating purposes in the United States. Euro-dollars have also served as a source of funds for banks that wished to obtain balances for operations in the market for call loans to securities brokers and dealers. Some foreign banks have used Euro-dollars for financing the operations of their affiliates, agencies, and branches in the United States because the dollar balances required for these purposes exceed the funds they are able to attract from U.S. sources. To a considerable extent, these flows have been encouraged by foreign monetary authorities, who have come to regard the Euro-dollar market as a convenient channel for returning to their own banks surplus dollar reserves which they acquired as a result of our balance of payments deficit. By appropriate interest rate policies and by providing attractive forward rate facilities, several central banks have induced their commercial banking systems to acquire officially held dollar balances for placement in the Euro-dollar market. To the extent that these balances are accepted by overseas branches of American banks and by other banks which pass them on to U.S. banks, foreign official dollar holdings are reduced and our official balance improves.

\section{Substitution Effects of the Euro-Dollar Market}

By its very existence the Euro-dollar market makes for significant substitutions in international financial transactions. On the one hand, it encourages foreign borrowers to substitute Euro-dollar loans for credit provided by U.S. sources, thus retarding the outflow of American capital. On the other hand, the Euro-dollar market provides foreign private investors with a substitute for the U.S. money market, thus diminishing the flow of private short-term capital into this country. To be sure, these effects can be-and have been-outweighed or reinforced by what might be called outside factors-by changes in lenders' and investors' preferences, by

\footnotetext{
${ }^{20}$ I2 C.F.R. $\$ 204.2$ (b) (Ig69).
} 
official regulations, by new institutional developments. Nevertheless, these built-in tendencies deserve a word of clarification.

The market mobilizes large amounts of foreign funds of various sorts and origins, and channels them to foreign banks that need additional resources for the financing of international trade and other transactions. Since these banks are able to tap the market in large amounts at a moment's notice, they become less interested in drawing on their credit lines in American banks for the financing of their customers. The overseas branches of American banks also find in the market a ready source of funds for their own operations and thus become less dependent on headoffice funds. Moreover, among the customers they thus finance with foreign funds are the foreign affiliates of major accounts on the books of their head offices; and since the affiliates find it easier to obtain loans abroad-not only from the overseas branches but also from other banks-American corporations find it less necessary to transfer funds to their foreign affliates for the purpose of financing short- and medium-term capital needs.

In brief, the market gives rise to an intensive use of foreign-held dollar balances for meeting the credit needs of borrowers outside the United States. And the resultant slowing in the growth of U.S.-source credit to foreigners has a beneficial effect on our balance of payments. Of course, since the advent of the balance of payments program in 1965 , the reduction of capital outflows has been primarily attributable to official actions rather than to a substitution of Euro-dollar loans for U.S. bank loans or for corporate transfers to affiliates. Yet the ample margin of unused quotas under the bank restraint program and much of the voluntary reduction of corporate transfers to affiliates testify to the ease with which foreign demands for dollars can be satisfied out of foreign-held dollar balances.

Incidentally, it should be noted that the beneficial payments effect of this substitution would be less pronounced if the United States used methods employed in some other countries for striking a balance in international accounts. For instance, if we were to compute our balance by netting our short-term banking claims against our short-term liabilities, any reduction in U.S. banks' short-term loans to foreigners induced by greater use of Euro-dollar balances for foreign loans would entail no benefit to our position.

When foreign banks use Euro-dollars for loan extensions to foreign borrowers, dollar balances are merely transferred from one foreigner to another, and our liquidity balance is therefore not affected. Such loans, however, may well affect our balance on official reserve transactions. For instance, if an overseas branch of an American bank reduces its balance in its head office in order to make a loan to a foreign corporation, or if a Swiss bank sells New York money market assets for the same reason, there is an adverse effect on our official balance, assuming, of course, that the loan proceeds end up in official hands.

The example just cited illustrates the other substitution effect mentioned above: 
the substitution of the Euro-dollar market for the U.S. money market as an outlet for the employment of funds by foreign private investors. Several factors contribute toward this tendency: the ease and convenience of placing funds in foreign banks that operate in the Euro-dollar market; the market's proximity to important investor groups; its breadth, and, at times, its relatively high interest rates. It is impossible to say for sure how large a part of the funds lodged in that market would have been placed in the New York money market had the Euro-dollar market not developed (apart from the London money market there are few alternative opportunities for the placement of funds). Quite possibly, however, in the absence of the attractive investment opportunities offered by the Euro-dollar market, commercial banks in many parts of the world would have held lesser amounts of cash reserves; and central banks might have absorbed larger amounts of domestic liquidity. On balance, it is probable that much of the stimulative influence of the market on flows of funds into the United States, discussed in the previous section, has been offset by the relative loss of attractiveness of our money market as an outlet for the investment of foreign liquid reserves. To the extent that there has been such a shift of funds from the U.S. money market, our official reserve transactions balance has been adversely affected.

\section{II}

\section{Capital Movenents Through the Euro-Bond Market}

The Euro-bond market has been a major source of funds for American corporations desirous of investing abroad. At the same time it has offered the international financial community an exceedingly attractive investment medium that has served as an alternative to portfolio investments in the United States. It has also provided foreign official and private borrowers an opportunity to obtain substantial resources which they acquired in the past primarily in U.S. capital and loan markets. Finally, the market has strengthened the vehicle-currency role of the dollar and thus added to the dollar transactions balance requirements of foreign banks and private investors.

\section{A. Euro-Bonds as a Means of Financing American Direct Investments Abroad}

In financing their foreign operations, American corporations draw from heterogeneous sources: domestic funds internally generated or acquired in our capital market or borrowed from U.S. banks; retained earnings and depreciation reserves of foreign affliates; and foreign loan and capital markets. Foreign banks have long been an important source for working capital borrowings of foreign affiliates. But only after the emergence of the Euro-bond market were American corporations able to obtain sizable foreign-source funds for their investment operations abroad.

In the early days of its existence, American corporations had little reason to 
make use of the Euro-bond market. The prevailing interest rates in the market were far too high, relative to rates in the United States, to make Euro-bond flotations worthwhile. However, rate considerations became less relevant after the introduction of the President's balance of payments program in 1965. In furtherance of this program, the Secretary of Commerce asked corporations to improve by fifteen to twenty per cent the aggregate of selected components of their individual payments balances with developed countries during that year. Among the devices suggested to achieve this improvement were a better trade balance, reduction in direct investment outflows, larger repatriation of foreign affliates' earnings, and resort to foreign borrowings. Thus, corporations that wished to step up their foreign investments but were unable to add sufficiently to their trade balance had a strong incentive to borrow abroad, and were quite willing to pay rates above those prevailing in the U.S. capital market.

In their search for foreign funds, U.S. corporations faced, in 1965 , a number of legal obstacles. ${ }^{23}$ Not only did their securities, to be salable in Europe, have to be free of withholding tax, but U.S. investors had to be precluded from purchasing them, as otherwise the balance of payments benefits derived from financing direct investment abroad through the Euro-bond market would have been offset by additional portfolio capital outflows. The establishment of international offshore finance subsidiaries in countries such as Luxembourg or the Netherlands Antilles served this objective. But both purposes were also served by the device of establishing international finance subsidiaries incorporated in the United States, the so-called Delaware corporations that can make public offerings of debt obligations guaranteed by their parent companies. As pointed out above, so long as their income is derived, to the extent of at least eighty per cent, from sources outside the United States, they do not have to withhold tax on interest paid to holders of these debt obligations. And, conversely, taxation deters U.S. investors from purchasing the bonds, since the interest equalization tax is applicable to the purchase of securities of U.S. corporations "formed or availed of for the principal purpose of obtaining funds for a foreign issuer or obligor." ${ }^{24}$ The Delaware corporations have been formed for this specific purpose.

The incentive for direct investors to borrow abroad was reinforced as the voluntary balance of payments program proceeded. The 1966 program requested that corporations limit their direct investments in $1965-66$ to ninety per cent of the amount invested during the three-year period $x 962-64$. For this purpose, "direct investment" was defined as the net outflow of funds from the United States plus undistributed profits of subsidiaries abroad. The companies participating in the program were specifically authorized, in computing their direct investments, to

\footnotetext{
${ }^{28}$ See Bross, The United States Borrower in the Eurobond Market-A Lawyer's Point of Viesu, in this symposium, p. -

26INT. Rev. CODE of 1954, \$4912(c).
} 
take credit for the proceeds of securities sold to foreigners for the purpose of financing the foreign affiliates. In 1967 , the quotas were materially reduced, and under the mandatory program introduced in 1968 the limitations were tightened even further. That program provided for a moratorium on the use of U.S. source funds for direct investment in the industrial countries of continental Europe and South Africa, and additional limitations elsewhere. Again direct investors were authorized to increase their aggregate investments in foreign affiliates without limit if the increase was attributable to investment of "long-term foreign borrowings."25

In response to this provision, many of the largest American corporations entered the Euro-bond market in 1968, offering very large amounts of bonds convertible into their common stock. These issues were enthusiastically received and almost always oversubscribed. Many issues were increased to meet the demands. Several mutual funds were set up abroad to purchase exclusively Euro-bond convertibles. Altogether, American corporations were able to obtain more than $\$ 2$ billion in the Euro-bond market during 1968, of which \$I.7 billion consisted of convertible bonds. This amount was supplemented by the long-term borrowings of the affiliates themselves. Altogether, U.S. corporations during 1968 actually obtained in foreign capital and loan markets resources adequate to meet their requirements not only for Ig68 but also for 1969 .

The mandatory program, like the voluntary programs that preceded it, authorized direct investors to exclude Euro-bond proceeds transferred to foreign affiliates from the calculation of the net use of their quota allowables. In the computation of our balance of payments accounts, analogous procedures apply. As a U.S.-incorporated finance subsidiary obtains funds from foreign buyers of its bonds, a long-term capital inflow into this country occurs. To the extent that the finance subsidiary transfers these dollars to its parent company's foreign affiliates, the funds are included in the direct investment capital outflow account in the U.S. balance of payments statement; thus, they are recorded as a part of aggregate direct investment funds transferred from the United States. If the finance subsidiary places the Euro-bond proceeds with foreign banks pending their transfer to foreign operating affliates, the funds appear as an outflow in the United States short-term capital account. In both cases the original long-term inflow is offset by a capital outflow. If the bonds are issued by an offshore finance subsidiary which invests them overseas, no entries are made in our balance of payments unless the funds are transferred to the parent company pending use abroad. Thus, borrowing in the Euro-bond market, to the extent that the proceeds are employed abroad, has no net effect on our balance of payments. However, a benefit to our balance occurs to the extent that American corporations use the proceeds of foreign borrowings as an alternative to use of their quotas under the Commerce Department's direct investment program. In that case, capital outflows from the United States are actually reduced. An additional benefit

\footnotetext{
${ }^{25}$ OFDI Reg. $\S_{313}$ (d)(I) (1968).
} 
is obtained when American corporations use the Euro-bond market for the purpose of obtaining funds for their domestic operations, as they did to some extent in Ig68.

Whether foreign borrowings reduced the use of U.S.-source funds and foreign earnings for direct investments during $1965-67$ is not entirely clear. During that three-year period, U.S.-incorporated companies floated issues of approximately \$r.3 billion in the Euro-bond market, but transferred only $\$ 775$ million to their foreign affiliates. The difference was almost entirely placed in the Euro-dollar market, pending later use for direct investment. The question is whether American corporations would have employed domestic funds and retained earnings of foreign affiliates in substantially larger amounts than allowed under the guidelines had they been unable to tap the Euro-bond market. The answer may well be that voluntary compliance with the program was much better than it would have been had there not been this alternative source of funds. There is no doubt that borrowing in the Euro-bond market, together with other borrowings by both parent companies and their overseas operating affiliates enabled American business to achieve the balance of payments goals of the voluntary program. Still it appears that in $1965-67$ the major result of foreign borrowings was probably an absolute increase in the corporations' total expenditures abroad for the acquisition of foreign corporations and of plant and equipment abroad, rather than a reduction in the outflow of U.S. capital.

In I968, as mentioned above, the Euro-bond issues by finance subsidiaries yielded more than $\$ 2$ billion, not including borrowings from foreign banks. Approximately $\$$ I.5 billion of these proceeds were used by direct investors to finance expenditures of their foreign operating affiliates. One reason why they made such heavy use of Euro-bond proceeds was the Commerce Department regulation requiring direct investors to use existing Euro-bond proceeds before taking advantage of their investment quotas. ${ }^{26}$ But more important were the severe pressures on corporations' domestic cash positions and the sharp increase in domestic money costs, together with the prospect of extremely tight credit conditions. As a result, toward the end of I968 U.S. direct investors actually repatriated Euro-bonds proceeds and other foreign borrowings in such amounts that there was an appreciable shortfall in the use of Ig68's quota allowables. Thus, Euro-bond proceeds made a major contribution in I 968 to the reduction of capital outflows from the United States.

An assessment of the balance of payments effects of these flows must take into account that a direct investor, if he does not make use of a quota allowable during a calendar year, may carry over the shortfall to the following year; a capital outflow reduction resulting from nonuse of investment allowables is not necessarily a permanent reduction. It can be argued too that the mandatory program would not

\footnotetext{
${ }^{28}$ OFDI Reg. $\$ 203$ (d)(I) (I969). In June, the OFDI proposed an amendment to $\$ 203$ (d)(I) exempting from its restrictions, any direct investor who elects the new million dollar minimum allowable under $\$ 503$, as amended, 34 Fed. Reg. 9067 (1969).
} 
have been practicable of enforcement had U.S. corporations not been able to turn to foreign capital markets for the financing of their overseas needs. Without this escape valve, the American business community would probably have demanded an easing of the severely restrictive quota provisions.

\section{B. Substitution of Euro-Bonds for American Securities}

Considerable uncertainy prevails also regarding the net effect produced on the U.S. balance of payments by foreign purchases of Delaware corporation and other Euro-bond issues. A widely debated question is whether these purchases of bonds, notably the convertible variety, have been financed through selling holdings of American securities to investors in this country. So far as this has occurred, U.S. corporations in effect have financed direct investment expenditures in excess of their quota allowables with funds obtained in the Unted States; net inflows of long-term capital into the United States would have thus been reduced, and our balance would have worsened accordingly. The results would have been the same if foreign investors in an effort to maintain predetermined portions of their aggregate portfolios in U.S. securities, have purchased new bonds issued by finance subsidiaries rather than U.S. equities.

The evidence on these questions is buried in statistics that cover a large variety of portfolio capital transactions. Those who deny that the issue of these securities has had a damaging effect on our balance can point to the fact that foreign purchases of U.S. equities expanded rapidly at the same time that the Delaware corporations were placing record amounts of convertible securities in foreign markets. It is obvious that there occurred during I968 a major reallocation of international investment portfolios in favor of U.S. corporate securities. U.S. corporations were quick to take advantage of foreign investors' almost insatiable appetite for these securities. It can undoubtedly be argued that the resounding success of the convertible bonds and the publicity associated with their issuance have attracted foreign investors' attention to American equities and therefore contributed toward the surge of foreign purchases in the New York stock market.

On the other hand, net foreign purchases may well have been reduced by foreign sales. Certainly it can be reasoned that it serves the self-interest of foreign investors to switch out of or forgo purchases of American equities and convertible bonds in order to acquire Euro-bonds. Compared with investments in the New York stock market, convertible issues of Delaware corporations look superior for several reasons. After the value of the underlying stock has passed the conversion price, the bond's quotation will be closely related to the equity's price on the New York stock exchange, but meanwhile the yield of the convertible bond remains far higher than that of the underlying issue. Because of this, during periods of declining stock prices, the market performance of bonds is typically much better than that of the underlying issue. Moreover, interest payments on Euro-bonds are free of tax while dividends on American equities held by foreigners are subject to withholding tax. 
Thus it is quite possible that net purchases of American equities by foreigners have been smaller than they would have been in the absence of the convertible bonds issued by Delaware corporations. Beyond doubt, foreign interest in convertible bonds issued in our domestic market has vanished as more attractive convertibles have become available abroad. Also, when foreign investors sell bonds in order to take profits, foreign arbitragers often buy them in order to convert them and pending conversion sell the underlying securities in the New York stock market for future delivery. Altogether, one should not make light of the contention of some knowledgeable observers that foreign investors have frequently purchased Eurobonds issued by American companies with funds obtained from the sale of U.S. equities and that their new purchases of American securities would have been larger in the absence of Euro-bond offerings.

\section{Other Effects of the Euro-Bond Market}

Capital outflows from the United States have been reduced by the Euro-bond market's increasing ability to absorb some of the foreign demand-both official and private-for long-term capital. The Euro-bond market has supplied a total of $\$ 5.5$ billion to foreign borrowers during the I962-68 period. This massive capital flow has surely diminished pressures on U.S. credit institutions from many foreign sources. The fact is that the U.S. capital market in any case would not have been able to meet all these demands in view of the effects of the interest equalization tax and the Federal Reserve Board's restraint program, which have limited American purchases of long-term securities issued by obligators located in developed countries other than Canada and Japan. But even after making allowance for these barriers, the Euro-bond market, in meeting a growing proportion of the world's long-term capital needs, has been of substantial benefit to the U.S. balance.

The emergence of the Euro-bond market has also given rise to substantial, though indeterminate, demands for dollars to serve as a medium for the settlement of international securities transactions. Most Euro-bonds have been denominated in dollars (German marks are the only other significant denomination). Most transactions in the secondary market for dollar-denominated Euro-bonds are settled in New York. Thus foreign investors, trading firms, and foreign issuers of bonds and their underwriting syndicates have had additional need for dollar working balances as they conduct operations in the Euro-bond market. The resulting increase in the net demand for dollars has strengthened the dollar in foreign exchange markets and has added importantly to the vehicle-currency status of the dollar.

\section{ConcLusron}

For the student of international financial markets and of government restraint on international capital movements, a review of the interaction between the Euromarkets and our balance of payments holds several significant lessons. It illustrates 
the adaptability of suppliers and users of funds to legal barriers that impede the free flow of international capital across national borders. The Euro-markets provide good examples of institutional arrangements that emerge in response to such barriers. Little did those who designed these legal roadblocks perceive the dynamic market processes that would evolve as a result.

The question suggests itself whether these markets would shrink or even disappear if the laws and regulations that have contributed to their emergence and fostered their growth were to be relaxed or removed. The answer is definitely in the negative. Markets have a life of their own. They become an integral part of the financial scene, surviving even if the rules that gave rise or impetus to them are modified or eliminated.

For instance, the eventual termination of the Federal Reserve Board's foreign credit restraint program is unlikely to spell the end of the large-scale use of foreign dollar balances for credit extensions by the overseas branches of U.S. banks and by foreign banks in general. And, even if the Federal Reserve Board were to remove its prohibition of interest payments on demand deposits or its rate ceilings on time deposits, U.S. banks would probably still have their branches bid for funds in the Euro-dollar market. Similarly, even after the Commerce Department's restrictions on the use of domestic funds for direct investments are permitted to lapse, U.S. corporations, having discovered the Euro-bond market's potential, are likely to use it whenever differentials between long-term rates here and abroad make drawing on the market attractive.

Another lesson to be derived from tracing capital movements through the Euromarket in response to regulatory obstacles is that some of the benefits of these regulations are less significant than appears at first sight. In some measure, these flows of funds preclude equally beneficial movements that would otherwise occur. Or the benefit is confined to a particular statistical measure of the balance of international transactions, while another equally significant measure remains unaffected. It is clear, however, that, on balance, capital movements through the Euro-markets have been highly beneficial to the U.S. balance of payments and the international position of the dollar.

A final observation appears pertinent. Any comprehensive control program that prevents powerful industrial and financial interests from using available and sorely needed resources requires, for its own survival, a built-in escape valve. Otherwise, the pressures and strains that such a program tends to generate will eventually tear it apart, or at least cause compliance to fall to such a low level as to deprive it of much of its effectiveness. By leaving open the escape route to the Euro-markets, the designers of our balance of payments program have stifled the inevitable opposition to its restraints, obtained a high degree of compliance, and made most businessmen and many bankers feel that they can somehow live with the program, even though not always comfortably. 